Article

\title{
Effect of Alkali-Doping on the Performance of Diatomite Supported Cu-Ni Bimetal Catalysts for Direct Synthesis of Dimethyl Carbonate
}

\author{
Dongmei Han ${ }^{1}$, Yong Chen ${ }^{2}$, Shuanjin Wang ${ }^{2}{ }^{(1)}, \operatorname{Min} \mathrm{Xiao}^{2, *}$, Yixin $\mathrm{Lu}^{3}$ and \\ Yuezhong Meng 1,2,* \\ 1 School of Chemical Engineering and Technology, Sun Yat-Sen University, Guangzhou 510275, China; \\ handongm@mail.sysu.edu.cn \\ 2 The Key Laboratory of Low-Carbon Chemistry \& Energy Conservation of Guangdong Province/State Key \\ Laboratory of Optoelectronic Materials and Technologies, Sun Yat-Sen University, Guangzhou 510275, \\ China; chenyong@lesso.com (Y.C.); wangshj@mail.sysu.edu.cn (S.W.) \\ 3 Department of Chemistry \& Medicinal Chemistry Program, Office of Life Sciences, National University of \\ Singapore, Singapore 117543, Singapore; chmlyx@nus.edu.sg \\ * Correspondence: stsxm@mail.sysu.edu.cn (M.X.); mengyzh@mail.sysu.edu.cn (Y.M.); \\ Tel./Fax: +86-20-8411-4113 (Y.M.)
}

Received: 28 June 2018; Accepted: 24 July 2018; Published: 27 July 2018

\begin{abstract}
Alkali-adopted $\mathrm{Cu}-\mathrm{Ni}$ /diatomite catalysts were designed and used for the direct synthesis of dimethyl carbonate (DMC) from carbon dioxide and methanol. Alkali additives were introduced into $\mathrm{Cu}-\mathrm{Ni}$ /diatomite catalyst as a promoter because of its lower work function $(\mathrm{Ni}>\mathrm{Cu}>\mathrm{Li}>$ $\mathrm{Na}>\mathrm{K}>\mathrm{Cs}$ ) and stronger electron-donating ability. A series of alkali-promoted $\mathrm{Cu}-\mathrm{Ni} /$ diatomite catalysts were prepared by wetness impregnation method with different kind and different loading of alkali. The synthesized catalysts were fully characterized by means of X-ray diffraction (XRD), scanning electron microscope (SEM), temperature-programmed reduction (TPR), and $\mathrm{NH}_{3} / \mathrm{CO}_{2}-\mathrm{TPD}$. The experimental results demonstrated that alkali adoption can significantly promote the catalytic activity of $\mathrm{Cu}-\mathrm{Ni}$ bimetallic catalysts. Under the catalytic reaction conditions of $120{ }^{\circ} \mathrm{C}$ and $1.0 \mathrm{MPa}$; the highest $\mathrm{CH}_{3} \mathrm{OH}$ conversion of $9.22 \%$ with DMC selectivity of $85.9 \%$ has been achieved when using $15 \%(2 \mathrm{Cu}-\mathrm{Ni}) 2 \% \mathrm{Cs}_{2} \mathrm{O} /$ diatomite catalyst $(\mathrm{CuO}+\mathrm{NiO}=15 \mathrm{wt}$. $\%$, atomic ratio of $\mathrm{Cu} / \mathrm{Ni}=2 / 1$, $\mathrm{Cs}_{2} \mathrm{O}=2$ wt. \%).
\end{abstract}

Keywords: diatomite; alkali oxide; dimethyl carbonate; catalysis; carbon dioxide

\section{Introduction}

Carbon dioxide, the main greenhouse gas, can be converted into useful hydrocarbons rather than viewing it as waste emission [1]. Dimethyl carbonate (DMC), an environment-friendly building block, has attracted much attention as methylating and carbonylating agents, fuel additives, as well as polar solvents [2-5]. Direct catalytic synthesis of DMC from carbon dioxide and methanol has attracted much interest recently, which is industrially and environment-friendly compared to conventional commercial processes such as methanolysis of phosgene [6], ester exchange process [7,8], and gas-phase oxidative carbonylation of methanol [9]. Therefore, direct synthesis of $\mathrm{DMC}$ from $\mathrm{CH}_{3} \mathrm{OH}$ and $\mathrm{CO}_{2}$ is highly desired as it is environment-benign by nature [2]. However, highly efficient utilization of $\mathrm{CO}_{2}$ is still a significant challenge because of its in-built thermodynamic stability and kinetic inert.

Many kinds of catalysts for the direct synthesis of $\mathrm{DMC}$ from $\mathrm{CO}_{2}$, and $\mathrm{CH}_{3} \mathrm{OH}$ has been reported, including organometallic compounds [10], potassium methoxide [11], $\mathrm{ZrO}$, $\mathrm{Ce}_{0.5} \mathrm{Zr}_{0.5} \mathrm{O}_{2}, \quad \mathrm{H}_{3} \mathrm{PW}_{12} \mathrm{O}_{4}-\mathrm{Ce}_{\mathrm{x}} \mathrm{Ti}_{1-\mathrm{x}} \mathrm{O}_{2}, \quad \mathrm{H}_{3} \mathrm{PO}_{4}-\mathrm{V}_{2} \mathrm{O}_{5}, \quad \mathrm{Co}_{1.5} \mathrm{PW}_{12} \mathrm{O}_{40}$, and $\mathrm{Rh} / \mathrm{Al}_{2} \mathrm{O}_{3}$ catalysts 
etc. [12-23]. Nevertheless, the performance of these catalysts has a long way to go. Therefore, a high-efficiency catalyst combined activation of $\mathrm{CO}_{2}$ and methanol is under study. Some interesting investigations disclosed introducing a copper and nickel composite for the direct synthesis of DMC. S. H. Zhong et al. investigated the catalysts $\mathrm{Cu}-\mathrm{Ni} / \mathrm{ZrO}_{2}-\mathrm{SiO}_{2}, \mathrm{Cu}-\mathrm{Ni} / \mathrm{MoO}_{3}-\mathrm{SiO}_{2}$, and $\mathrm{Cu}-\mathrm{Ni} / \mathrm{V}_{2} \mathrm{O}_{5}-\mathrm{SiO}_{2}$ for this catalytic reaction [24-27]. In our previous studies, X.L Wu et al. further optimized the preparation conditions and catalytic process of the $\mathrm{Cu}-\mathrm{Ni} / \mathrm{VSO}$ catalyst. In order to enhance the yield of DMC [28], X.J Wang et al. reported the similar $\mathrm{Cu}-(\mathrm{Ni}, \mathrm{V}, \mathrm{O}) / \mathrm{SiO}_{2}$ catalysts with UV irradiation and pushed DMC yield close to 5\% [29]. Following the progress of peers, a significant enhancement in catalytic activity and stability was achieved by J. Bian et al. [20-35].

Although the catalysts above-mentioned offer different advantages over others, considerable shortcomings still exist, such as a complicated preparation process, expensive support materials, and bleak prospects for large-scale preparation; moreover, some environment-destructive agents such as $\mathrm{H}_{2} \mathrm{SO}_{4}, \mathrm{HF}$, and $\mathrm{K}_{2} \mathrm{MnO}_{4}$ were introduced during the process. Therefore, the investigation on the catalysts containing $\mathrm{Cu}-\mathrm{Ni}$ bimetal, low-cost support, and high catalytic performance are much more meaningful from a practical point of view. In our previous work, a series of diatomite-immobilized $\mathrm{Cu}-\mathrm{Ni}$ bimetallic nanocatalysts were prepared for the direct synthesis of dimethyl carbonate. The $\mathrm{Cu}-\mathrm{Ni}$ bimetallic components supported on conductive carbon materials were reported [36]. It is found that the bimetallic composite is effectively alloyed and well immobilized inside or outside the pore of diatomite. Under the optimal conditions of $1.2 \mathrm{MPa}$ and $120^{\circ} \mathrm{C}$, the prepared catalyst with loading of $15 \%$ exhibited the highest methanol conversion of $6.50 \%$ with DMC selectivity of $91.2 \%$ as well as more than $10 \mathrm{~h}$ lifetime [36].

Alkali additives are known to improve many industrially catalytic reactions such as ammonia and Fisher-Tropsch synthesis [37], CO oxidation and hydrogenation [38], and water-gas shift reaction [39,40]. It can induce a strong promotional effect on the performance of the catalysts such as enhanced activity and selectivity, suppression of undesirable reactions and improved catalyst stability. In this contribution, alkali-doped $\mathrm{Cu}-\mathrm{Ni} /$ diatomite and pure $\mathrm{Cu}-\mathrm{Ni}$ /diatomite bimetallic catalysts were prepared and characterized. The promotional effect of alkali on the dispersion, reduction, and activity of the catalyst are investigated in detail.

\section{Results and Discussion}

\subsection{Fourier-Transform Infrared Spectroscopy (FTIR) Analysis of Diatomite}

The FTIR spectrum of diatomite was recorded on an Analect RFX-65A type FTIR spectrophotometer with $\mathrm{KBr}$ matrix in region $450-4000 \mathrm{~cm}^{-1}$. And the results are shown in Figure 1 . The adsorption signature of $-\mathrm{OH}$ antisymmetric stretching vibration was exhibited at $3445 \mathrm{~cm}^{-1}$. The - $\mathrm{OH}$ group was affected by the hydrogen bond coming from the adsorbed water on the surface, including pore water, and water bonded to the surface hydroxyl group. A broadband absorption signature at $1091 \mathrm{~cm}^{-1}$ and a shoulder absorption signature at $1200 \mathrm{~cm}^{-1}$ are attributed to Si-O antisymmetric stretching vibration. The absorption band at $471 \mathrm{~cm}^{-1}$ is attributed to the antisymmetric bending vibration of $\mathrm{O}-\mathrm{Si}-\mathrm{O}$ in $\mathrm{SiO}_{4}$ tetrahedron. These spectrum features are consistent with amorphous $\mathrm{SiO}_{2}$, which reflects the vibration characteristics of the $\mathrm{SiO}_{4}$ tetrahedron of amorphous samples [41]. The hydroxyl groups existing on the surface and in the voids of the diatomite are extremely important for the infiltration of the precursor in and impregnated solution, and the adsorption and dispersion of the precursor on/in the diatomite.

\subsection{Decomposition and Reduction Study of the Catalyst Precursor}

The as-prepared $\mathrm{Cu}-\mathrm{Ni}-\mathrm{M}$ ammonia complex precursors were firstly investigated by thermogravimetric analysis (TGA) as shown in Figure 2. All the precursors exhibited clearly two-step decomposition. However, it is obvious that the decomposition temperature of alkali doped precursors is lower than that of the undoped precursor, which may result from the effect of distribution and 
induction of alkalis. It indicates a little lag around $300{ }^{\circ} \mathrm{C}$ at the end of the second decomposition step, which could be ascribed to the more difficult decomposition of alkali nitrate. Moreover, the decomposition completes much earlier with the increase of basicity and the decrease of potassium content for potassium doped precursors.

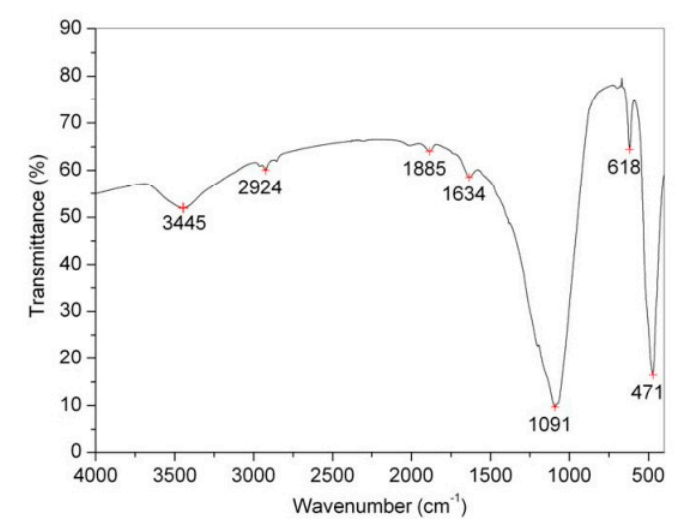

Figure 1. Fourier-transform infrared spectroscopy (FTIR) spectrum of diatomite.

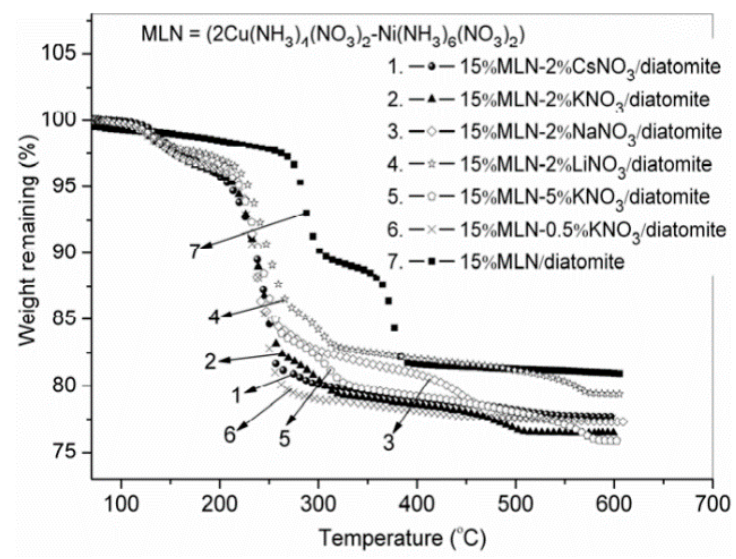

Figure 2. Thermogravimetric analysis (TGA) traces of catalyst precursor.

The calcined catalysts precursors were reduced by $5 \% \mathrm{H}_{2}$ purging (Figure 3). The $\mathrm{CuO}-\mathrm{NiO} /$ diatomite shows two obvious overlapped reduction peaks of $\mathrm{CuO}\left(\sim 303^{\circ} \mathrm{C}\right)$ and $\mathrm{NiO}\left(\sim 344^{\circ} \mathrm{C}\right)$, respectively. The precursors doped with alkalis show one obvious combined reduction peak rather than overlapping combined reduction peaks, and all of them could be fully reduced below $400{ }^{\circ} \mathrm{C}$. This may originate from the effect of distribution strongly promoted by alkali and the stronger reducibility induced by oxygen bridge bond between alkali and $\mathrm{CuO} / \mathrm{NiO}(\mathrm{M}-\mathrm{O}-\mathrm{Cu} / \mathrm{Ni})$ because of its much stronger adsorptive ability to $\mathrm{H}_{2}$ [24]. Furthermore, it shifts to a slightly higher reduction temperature due to the less electron-accepted ability of the oxygen bridge bond with the increase of alkali basicity. The main reduction temperature increases from $309^{\circ} \mathrm{C}$ to $325^{\circ} \mathrm{C}$ with the increase of alkali basicity under the same content of alkali oxides (Figure $3 b$ ). 

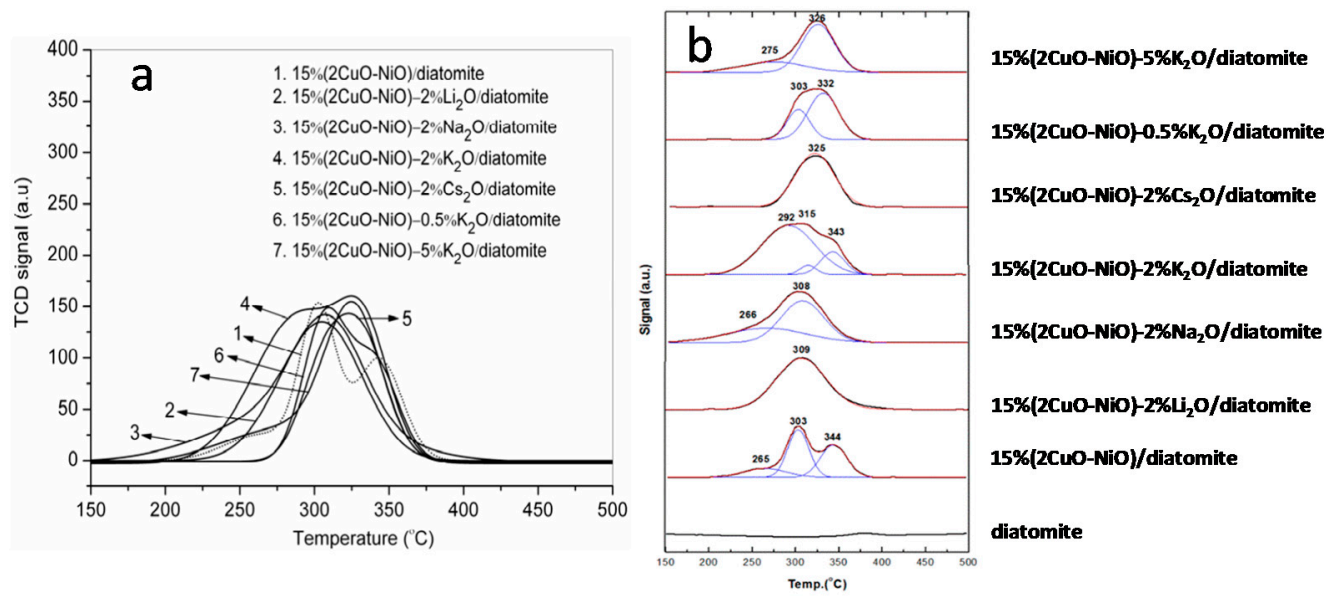

Figure 3. Temperature-programmed reduction (TPR) (a) and corresponding fitting curves (b) of calcined catalyst precursor.

\subsection{Textural Investigation of the Catalyst}

The powder X-Ray diffraction (XRD) study of alkali-doped and undoped $\mathrm{Cu}-\mathrm{Ni} /$ diatomite are presented in Figure 4. All catalysts show four typical diffraction peaks of $\mathrm{Cu}-\mathrm{Ni}$ alloy or $\mathrm{Cu} / \mathrm{Ni}$ around $2 \theta$ value of 43.75 (111), 50.88 (200), 74.98 (220), and 91.13 (311) with very few diffraction peaks of $\mathrm{CuO} / \mathrm{NiO}$. Moreover, the weak diffraction peaks of 200, 220, and 311 become weaker and broader with increasing the basicity of alkali due to the alkali-promoted effect of lattice destruction and grain refinement, especially for cesium-doped catalyst, indicating that much stronger basicity of alkali is more favorable for the stabilization of the nano-particles. The same trend was also observed with increasing amount of $\mathrm{K}_{2} \mathrm{O}$, which resulted from the effect of potassium-promoted physical distribution. The effect of grain refinement may attribute to alkali as the nucleation agent for $\mathrm{Cu}-\mathrm{Ni}$ precursor crystallization.

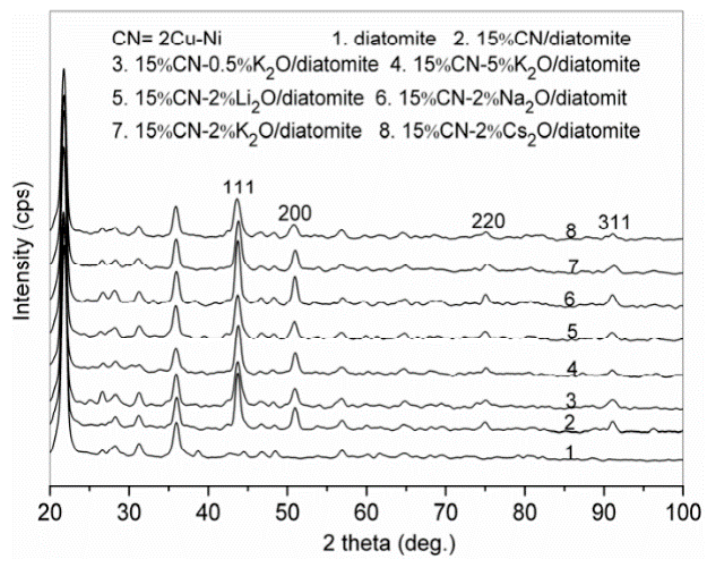

Figure 4. Powder X-ray diffraction (XRD) of the samples.

The morphology observation was conducted using scanning electron microscope (SEM) as shown in Figure 5. Figure 5a shows the natural diatomite and Figure $5 \mathrm{~b}$ the treated diatomite, while Figure $5 \mathrm{c}$ shows the $\mathrm{Cu}-\mathrm{Ni}$ /diatomite, Figure $5 \mathrm{~d}-\mathrm{g}$ shows the $\mathrm{Cu}-\mathrm{Ni}$ /diatomite doped with $2 \%$ of $\mathrm{LiO}_{2}, \mathrm{Na}_{2} \mathrm{O}, \mathrm{K} 2 \mathrm{O}$, and $\mathrm{Cs}_{2} \mathrm{O}$ in turn; the particle sizes of these catalysts decrease with the increase of the alkali basicity. Finally, the catalysts doped with $0.5 \% \mathrm{~K}_{2} \mathrm{O}$ in Figure $5 \mathrm{~h}$ and $5 \% \mathrm{~K}_{2} \mathrm{O}$ in Figure 5i, compared with Figure $5 \mathrm{f}$, evince that the particle size decreases with increasing the amount of $\mathrm{K}_{2} \mathrm{O}$, which is consistent with the result of XRD patterns. It indicates that the alkali doped Cu-Ni 
catalyst can facilitate the decomposition and reduction of $\mathrm{Cu}-\mathrm{Ni}$ catalyst precursors at a much lower temperature. In addition, the alkali clusters dispersed in $\mathrm{Cu}-\mathrm{Ni}$ crystallites could prevent the adjacent $\mathrm{Cu}-\mathrm{Ni}$ grains from excessive growth at high temperature and thus stabilize the $\mathrm{Cu}-\mathrm{Ni}$ crystallites. Consequently, more active sites of $\mathrm{Cu}-\mathrm{Ni}$ surface containing alkali are exposed on the surface of reactant molecules, which favorites the catalytic reaction. A Transmission electron microscopy (TEM) image of $15 \%(2 \mathrm{Cu}-\mathrm{Ni})-2 \% \mathrm{~K}_{2} \mathrm{O} /$ diatomite catalyst is shown in Figure 6 ; it can be seen that the catalyst particles are evenly dispersed on the diatomite support, and the particle size of the catalyst is about $20 \mathrm{~nm}$. It could provide a high specific surface area and result in high utilization.
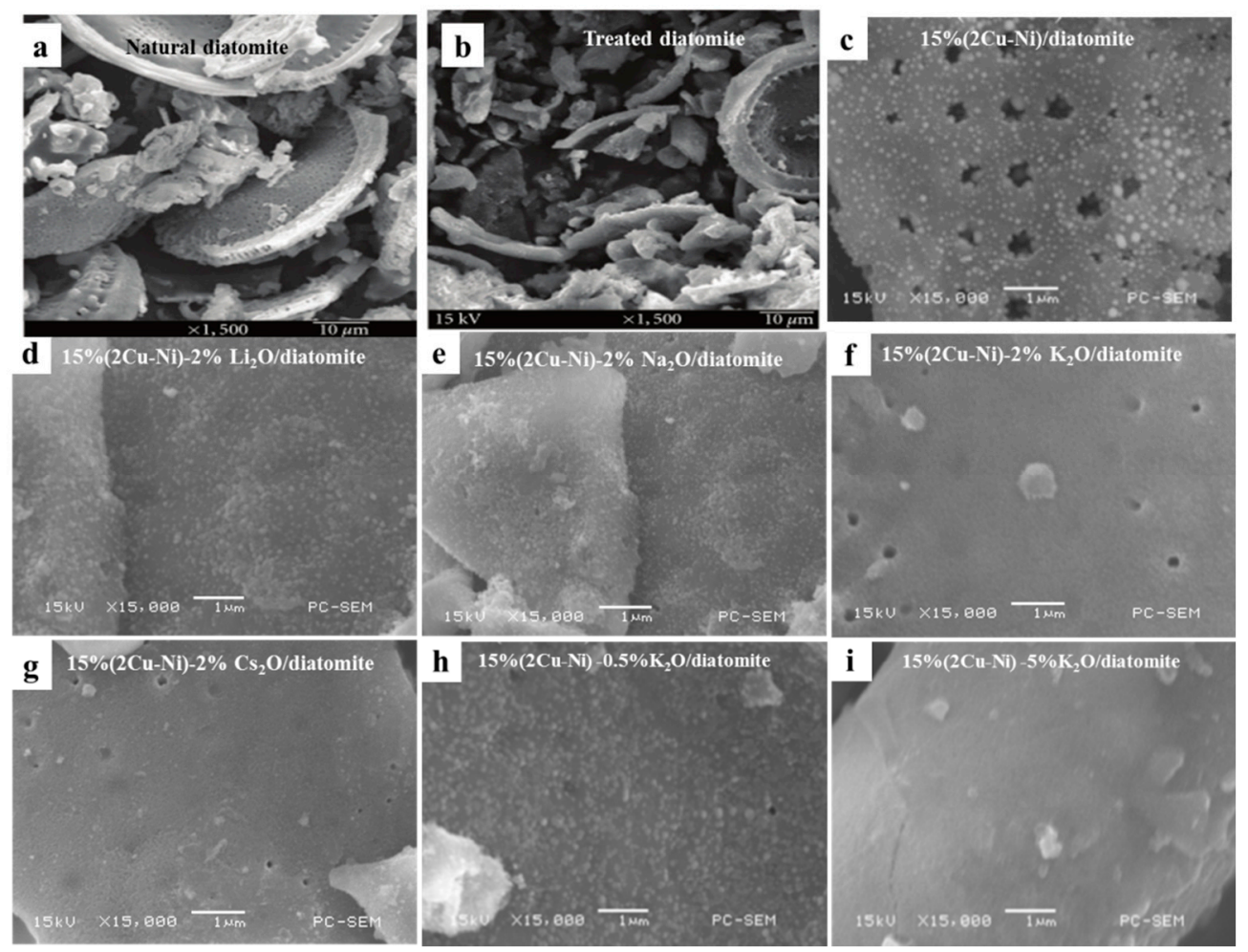

Figure 5. Scanning electron micrographic images of the samples.

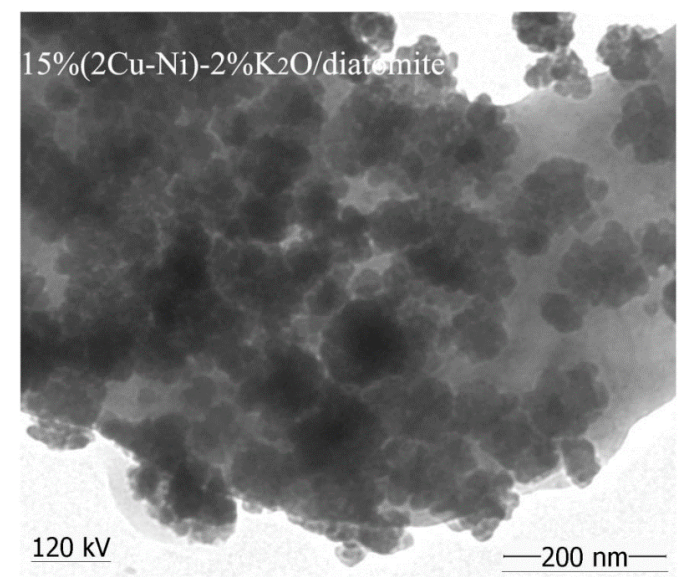

Figure 6. Transmission electron microscopy (EM) image of $15 \%(2 \mathrm{Cu}-\mathrm{Ni})-2 \% \mathrm{~K}_{2} \mathrm{O} /$ diatomite catalyst. 


\subsection{Adsorptive Behavior of the Catalyst}

The adsorptive properties of the catalyst samples were examined by $\mathrm{CO}_{2}$-TPD (Temperature-Programmed Desorption) and $\mathrm{NH}_{3}-\mathrm{TPD}$, respectively. As shown in Figure 7, the catalysts doped with alkali exhibit much stronger $\mathrm{CO}_{2}$ desorption than the undoped catalyst. In addition, the desorption peak slightly shifts to a higher temperature with the increase of alkali basicity, from a $157^{\circ} \mathrm{C}$ increase to $223^{\circ} \mathrm{C}$, which increases from $199^{\circ} \mathrm{C}$ to $231{ }^{\circ} \mathrm{C}$ with the increase of $\mathrm{K}_{2} \mathrm{O}$ content, respectively. According to Figure 7 and Table 1, it gradually shows a trend of two peaks with the increase of alkali basicity. This indicates a greater ability of $\mathrm{CO}_{2}$ activation, due to the well-dispersed alkali clusters in $\mathrm{Cu}-\mathrm{Ni}$. Figure 8 presents the $\mathrm{NH}_{3}$-TPD curves of as-prepared catalyst samples. The samples doped with alkali exhibit a little higher desorption temperature than the undoped catalyst (from $186^{\circ} \mathrm{C}$ increase to $207^{\circ} \mathrm{C}$ ), but which decrease slightly with the $\mathrm{Cs}_{2} \mathrm{O}$ doping. The details could be seen from Figure 8 and Table 2. It demonstrates that the introduction of alkali into $\mathrm{Cu}-\mathrm{Ni}$ composites intensified the $\mathrm{NH}_{3}$ desorption. Presumably, this is due to the effect of alkali-promoted dispersion and alkali-induced electron distributions of $\mathrm{Cu}-\mathrm{Ni}$ bimetal. This provides more unsaturated complex centers for the adsorption of $\mathrm{NH}_{3}$ and the activation of $\mathrm{CO}_{2}$.
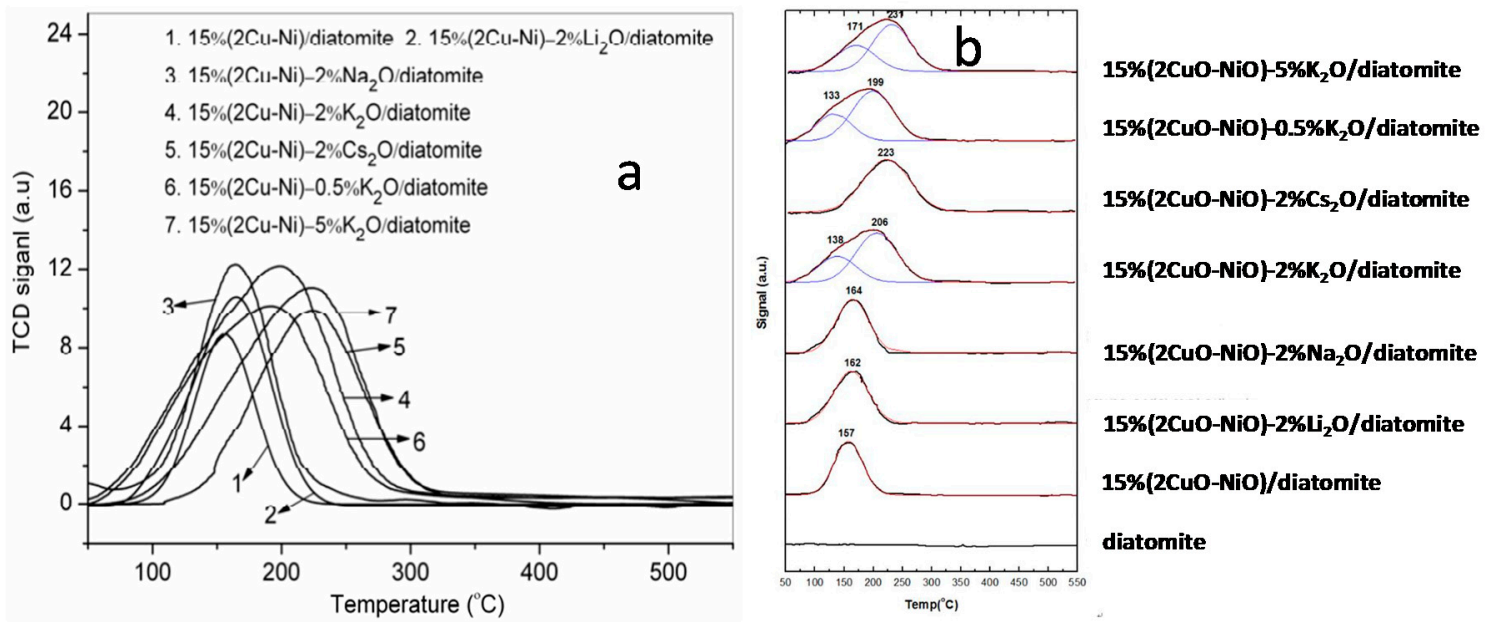

Figure 7. $\mathrm{CO}_{2}$ Temperature-programmed desorption curves (a) and their fitting curves (b) of the samples.

Table 1. Quantification of the $\mathrm{CO}_{2}$-TPD profiles of as-prepared catalysts.

\begin{tabular}{|c|c|c|c|}
\hline Samples & $\mathrm{T}^{\mathrm{a}}\left({ }^{\circ} \mathrm{C}\right)$ & Amount $^{b}\left(\mu\right.$ mol gcat $\left.^{-1}\right)$ & Total $^{\mathrm{c}}$ \\
\hline Diatomite & - & - & - \\
\hline $15 \%(2 \mathrm{CuO}-\mathrm{NiO}) /$ diatomite & 157 & 5.45 & 5.45 \\
\hline $15 \%(2 \mathrm{CuO}-\mathrm{NiO})-2 \% \mathrm{Li}_{2} \mathrm{O} /$ diatomite & 162 & 7.61 & 7.61 \\
\hline $15 \%(2 \mathrm{CuO}-\mathrm{NiO})-2 \% \mathrm{Na}_{2} \mathrm{O} /$ diatomite & 164 & 8.39 & 8.39 \\
\hline $15 \%(2 \mathrm{CuO}-\mathrm{NiO})-2 \% \mathrm{~K}_{2} \mathrm{O} /$ diatomite & $\begin{array}{l}138 \\
206\end{array}$ & $\begin{array}{l}4.75 \\
9.79\end{array}$ & 14.54 \\
\hline $15 \%(2 \mathrm{CuO}-\mathrm{NiO})-2 \% \mathrm{Cs}_{2} \mathrm{O} /$ diatomite & 223 & 9.71 & 9.71 \\
\hline $15 \%(2 \mathrm{CuO}-\mathrm{NiO})-0.5 \% \mathrm{~K}_{2} \mathrm{O} /$ diatomite & $\begin{array}{l}133 \\
199\end{array}$ & $\begin{array}{l}3.75 \\
8.09\end{array}$ & 11.84 \\
\hline $15 \%(2 \mathrm{CuO}-\mathrm{NiO})-5 \% \mathrm{~K}_{2} \mathrm{O} /$ diatomite & $\begin{array}{l}171 \\
231\end{array}$ & $\begin{array}{l}4.40 \\
7.85\end{array}$ & 12.25 \\
\hline
\end{tabular}

a Peak temperature of fitting curves; ${ }^{\mathrm{b}}$ Amount of absorption $\mathrm{NH}_{3}$ ( $\left.\mu \mathrm{mol}\right)$ per gram catalyst according to each peak;

c Total amount of absorption $\mathrm{NH}_{3}(\mu \mathrm{mol})$ per gram catalyst. 
Table 2. Quantification of the $\mathrm{NH}_{3}$-TPD profiles of as-prepared catalysts.

\begin{tabular}{lccc}
\hline \multicolumn{1}{c}{ Samples } & $\mathbf{T}^{\mathbf{a}}\left({ }^{\circ} \mathbf{C}\right)$ & Amount $^{\mathbf{b}}\left(\mu\right.$ mol gcat $\left.^{-1}\right)$ & Total $^{\mathbf{c}}$ \\
\hline diatomite & - & - & - \\
\hline \multirow{2}{*}{$15 \%(2 \mathrm{CuO}-\mathrm{NiO}) /$ diatomite } & 134 & 1.87 & 5.64 \\
& 186 & 2.36 & \\
\hline $15 \%(2 \mathrm{CuO}-\mathrm{NiO})-2 \% \mathrm{Li}_{2} \mathrm{O} /$ diatomite & 200 & 1.41 & 6.60 \\
\hline $15 \%(2 \mathrm{CuO}-\mathrm{NiO})-2 \% \mathrm{Na}_{2} \mathrm{O} /$ diatomite & 202 & 6.60 & 9.96 \\
\hline $15 \%(2 \mathrm{CuO}-\mathrm{NiO})-2 \% \mathrm{~K}_{2} \mathrm{O} /$ diatomite & 207 & 9.96 & 11.3 \\
\hline $15 \%(2 \mathrm{CuO}-\mathrm{NiO})-2 \% \mathrm{Cs}_{2} \mathrm{O} /$ diatomite & 185 & 11.3 & 11.2
\end{tabular}

a Peak temperature of fitting curves; ${ }^{\mathrm{b}}$ Amount of absorption $\mathrm{NH}_{3}(\mu \mathrm{mol})$ per gram catalyst according to each peak;

c Total amount of absorption $\mathrm{NH}_{3}(\mu \mathrm{mol})$ per gram catalyst.
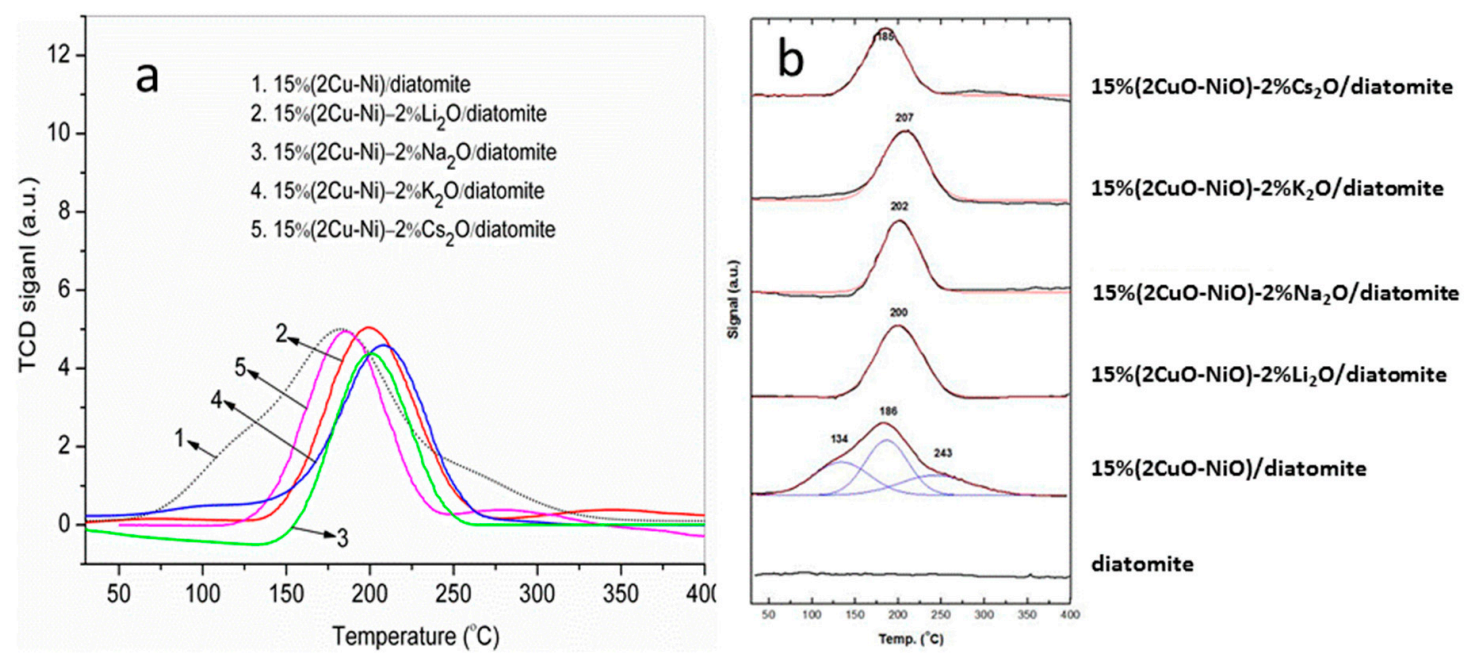

Figure 8. $\mathrm{NH}_{3}$ Temperature-programmed desorption curves (a) and their fitting curves (b) of the samples.

\subsection{Effect of Alkali on the Activity of Catalyst}

As listed in Table 3, 15\%(2Cu-Ni)/diatomite doped with different kinds and different amounts of alkali were prepared and studied. For the catalyst doped with $\mathrm{Li}_{2} \mathrm{O}$, the methanol conversion decreases from 6.11 to $2.77 \%$ with an increase of the $\mathrm{Li}_{2} \mathrm{O}$ content. This is probably due to the destruction of the $\mathrm{Cu}-\mathrm{Ni}$ alloy composite and the formation of the $\mathrm{Cu}-\mathrm{Li}$ alloy. As for the catalysts doped with $\mathrm{Na}_{2} \mathrm{O}$, $\mathrm{K}_{2} \mathrm{O}$, and $\mathrm{Cs}_{2} \mathrm{O}$ in turns, the catalytic activity increases with alkali dopant loading and reaches the highest value at $2 \mathrm{wt} \%$ doping content $(7.92 \mathrm{~mol} \%)$. The highest doping content of $5 \mathrm{wt} \%$ results in the lowest activity, likely owing to the excessive dopant surfacing on $\mathrm{Cu}-\mathrm{Ni}$, which can poison the active center of the $\mathrm{Cu}-\mathrm{Ni}$ composites. Moreover, it seems that the catalytic activity is increased by increasing the basicity of dopant. It is believed that $\mathrm{Na}_{2} \mathrm{O}, \mathrm{K}_{2} \mathrm{O}$, and $\mathrm{Cs}_{2} \mathrm{O}$ are solidified together with $\mathrm{CuO}-\mathrm{NiO}$ during calcination when preparing catalysts. As a result, $\mathrm{Na}, \mathrm{K}$, and $\mathrm{Cs}$ can then immigrate into the lattice of the $\mathrm{Cu}-\mathrm{Ni}$ alloy composite. Thus $\mathrm{Cu}-\mathrm{Ni}$-alkali $(\mathrm{Na}, \mathrm{K}$, and $\mathrm{Cs}$ ) can be partly alloyed on the interface of the alkali oxide and $\mathrm{Cu}-\mathrm{Ni}$ during the process of reduction. In conclusion, the introduction of alkalis into $\mathrm{Cu}-\mathrm{Ni}$ lattice can promote the polarization of $\mathrm{Cu}-\mathrm{Ni}$ lattice and speed up the electron transformation from $\mathrm{Cu}-\mathrm{Ni}$ to $\mathrm{CO}_{2}$, which in turn activates the reaction between methanol and $\mathrm{CO}_{2}$. Compared with V-doped $\mathrm{Cu}-\mathrm{Ni}$ catalyst [31], this method provides an effective and economic way for the direct synthesis of DMC, and would trigger much more interest in peer work. 
Table 3. Influence of alkali loading on catalytic performance of $15 \%(2 \mathrm{Cu}-\mathrm{Ni}) /$ diatomite.

\begin{tabular}{lccc}
\hline \multicolumn{1}{c}{ Catalyst $^{\mathbf{a}}$} & $\begin{array}{c}\text { Methanol Conversion } \\
\left(\mathbf{m o l} \% \mathbf{~}^{\mathbf{b}, \mathbf{c}}\right.\end{array}$ & $\begin{array}{c}\text { DMC Selectivity } \\
\left(\mathbf{m o l} \% \mathbf{~}^{\mathbf{c}}\right.\end{array}$ & DMC Yield (mol \%) \\
\hline $15 \%(2 \mathrm{Cu}-\mathrm{Ni}) /$ diatomite & 6.50 & 91.2 & 5.93 \\
$15 \%(2 \mathrm{Cu}-\mathrm{Ni})-0.5 \% \mathrm{Li}_{2} \mathrm{O} /$ diatomite & 6.11 & 88.2 & 5.39 \\
$15 \%(2 \mathrm{Cu}-\mathrm{Ni})-2 \% \mathrm{Li}_{2} \mathrm{O} /$ diatomite & 5.68 & 83.2 & 4.73 \\
$15 \%(2 \mathrm{Cu}-\mathrm{Ni})-5 \% \mathrm{Li}_{2} \mathrm{O} /$ diatomite & 2.77 & 85.1 & 2.36 \\
$15 \%(2 \mathrm{Cu}-\mathrm{Ni})-0.5 \% \mathrm{Na}_{2} \mathrm{O} /$ diatomite & 6.68 & 83.3 & 5.56 \\
$15 \%(2 \mathrm{Cu}-\mathrm{Ni})-2 \% \mathrm{Na}_{2} \mathrm{O} /$ diatomite & 7.02 & 84.5 & 5.93 \\
$15 \%(2 \mathrm{Cu}-\mathrm{Ni})-5 \% \mathrm{Na}_{2} \mathrm{O} /$ diatomite & 3.97 & 81.7 & 3.24 \\
$15 \%(2 \mathrm{Cu}-\mathrm{Ni})-0.5 \% \mathrm{~K}_{2} \mathrm{O} /$ diatomite & 6.81 & 89.2 & 6.08 \\
$15 \%(2 \mathrm{Cu}-\mathrm{Ni})-2 \% \mathrm{~K}_{2} \mathrm{O} /$ diatomite & 7.55 & 90.3 & 6.82 \\
$15 \%(2 \mathrm{Cu}-\mathrm{Ni})-5 \% \mathrm{~K}_{2} \mathrm{O} /$ diatomite & 3.68 & 84.8 & 3.12 \\
$15 \%(2 \mathrm{Cu}-\mathrm{Ni})-0.5 \% \mathrm{Cs}_{2} \mathrm{O} /$ diatomite & 7.17 & 90.7 & 6.50 \\
$15 \%(2 \mathrm{Cu}-\mathrm{Ni})-2 \% \mathrm{Cs}_{2} \mathrm{O} /$ diatomite & 9.22 & 85.9 & 7.92 \\
$15 \%(2 \mathrm{Cu}-\mathrm{Ni})-5 \% \mathrm{Cs}_{2} \mathrm{O} /$ diatomite & 5.65 & 80.4 & 4.54 \\
\hline
\end{tabular}

${ }^{a}$ Molar ratio of $\mathrm{CuO} / \mathrm{NiO}$ is $2 / 1$, all metal contents are calculated by mass of corresponding metal oxide; ${ }^{\mathrm{b}} \mathrm{DMC}$ yield is calculated based on the amount of methanol; ${ }^{\mathrm{C}}$ Reaction conditions: $120^{\circ} \mathrm{C} ; 1.0 \mathrm{Mpa} ; \mathrm{CO}_{2}$ flux $(15 \mathrm{~mL} / \mathrm{min})$.

\section{Experimental}

\subsection{Catalyst Preparation}

$\mathrm{Cu}-\mathrm{Ni}-\mathrm{M}$ / diatomite $(\mathrm{M}=\mathrm{Li}, \mathrm{Na}, \mathrm{K}, \mathrm{Cs})$ nanocatalysts were prepared by the wetness impregnation method. Firstly $\mathrm{Cu}\left(\mathrm{NO}_{3}\right)_{2} \cdot 3 \mathrm{H}_{2} \mathrm{O}, \mathrm{Ni}\left(\mathrm{NO}_{3}\right)_{2} \cdot 6 \mathrm{H}_{2} \mathrm{O}$ and alkali nitrate were dissolved in ammonia solution with stirring, and then natural diatomite was dispersed in metallic ammonia solution. The resulting mixture was stirred at room temperature for $24 \mathrm{~h}$, ultrasonicated for another $3 \mathrm{~h}$, followed by rotavaporation to remove the solvent. Thereafter, it was dried at $110^{\circ} \mathrm{C}$ overnight. The fully dried solid was calcining at $500{ }^{\circ} \mathrm{C}$ for $3 \mathrm{~h}$ and further reduced by $5 \% \mathrm{H}_{2} / \mathrm{N}_{2}$ mixture at $550{ }^{\circ} \mathrm{C}$ for $6 \mathrm{~h}$.

\subsection{Catalyst Characterization}

TGA of samples were performed on a PerkinElmer Pyris Diamond SII thermal analyzer (high-purity $\mathrm{N}_{2}, 20{ }^{\circ} \mathrm{C} / \mathrm{min}$ ). The morphologies of the samples were characterized using a SEM (JSM-5600LV, JEOL, Tokyo, Japan) equipped with an EDX to check the components of the catalysts. The phase structure of the samples was determined by XRD on a D/Max-IIIA power diffractometer (Rigaku Corporation, Tokyo, Japan) using $\mathrm{Cu}(\mathrm{K} \alpha)(0.15406 \mathrm{~nm})$ radiation source. Temperature programmed reduction (TPR) and Temperature programmed desorption of ammonia $\left(\mathrm{NH}_{3}-\mathrm{TPD}\right)$ / carbon dioxide ( $\left.\mathrm{CO}_{2}-\mathrm{TPD}\right)$ experiments of the samples were detected by Quantachrom ChemBET 3000 apparatus (Quantachrom Instruments, Boynton Beach, FL, USA) equipped with a thermal conductivity detector (TCD) [31].

The evaluation of the catalysts was performed in a continuous tubular fixed-bed micro-gaseous reactor with $2 \mathrm{~g}$ of the fresh catalyst and set molar ratio of $\mathrm{CH}_{3} \mathrm{OH}$ bubbled into the reactor by $\mathrm{CO}_{2}$ $\left(30 \mathrm{~mL} / \mathrm{min}\right.$ flux). It was carried out under set conditions of $120^{\circ} \mathrm{C}$ and $1.2 \mathrm{MPa}$. The products were analyzed by on-line GC (GC7890F) (TECHCOMP CORPORATE, Shang Hai, China) equipped with a flame ionization detector and GCMS-QP2010 Plus (SHIMADZU CORPORATION, Tokyo, Japan). The final results were calculated by the following Equations (1)-(3):

$$
\begin{gathered}
\mathrm{CH}_{3} \mathrm{OH} \text { conversion }(\mathrm{mol} \%)=\frac{\left[\mathrm{CH}_{3} \mathrm{OH}\right]_{\text {reacted }}}{\left[\mathrm{CH}_{3} \mathrm{OH}\right]_{\text {total }}} \times 100 \% \\
\text { DMC selevtivity }(\mathrm{mol} \%)=\frac{[\mathrm{DMC}]}{[\mathrm{DMC}]+[\text { Byproduct }]} \times 100 \% \\
\text { DMC yield }(\mathrm{mol} \%)=\mathrm{CH}_{3} \mathrm{OH} \text { conversion } \times \text { DMCselevtivity }
\end{gathered}
$$




\section{Conclusions}

Based on the SEM, TPR/TPD investigation of the activity and stability evaluation of the alkali-doped catalyst, we can conclude that the incorporation of alkali is conducive to the preparation of the catalysts precursor by decreasing the decomposition and reduction temperatures, which is favorable for the formation of a nano-scale dispersion of bimetalic particles on the surface of supports. The well-dispersed characteristic in turn endows the catalyst with more lattice drawbacks and a polarized $\mathrm{Cu}-\mathrm{Ni}$ lattice. This effect becomes more obvious with increasing the basicity of alkali. The catalytic activity of the alkali-promoted catalyst is enhanced with the increase of alkali basicity, except lithium oxide, indicating alkali doping can significantly improve the catalytic efficiency of $\mathrm{Cu}-\mathrm{Ni}$ composites. This preliminary study provides a new practical way to improve the efficiency of DMC synthesis, which will promote related research and peer distribution in this hot research area.

Author Contributions: D.H., Y.C., Y.M., S.W. and M.X. conceived and designed the experiments; D.H. and Y.C. performed the experiments and analyzed the data; Y.L. and S.W. contributed analysis tools. D.H. wrote this paper.

Acknowledgments: This research was funded by the National Natural Science Foundation of China (Grant No. 21376276, 21643002), Guangdong Province Sci \& Tech Bureau (Grant No. 2017B090901003, 2016B010114004, 2016A050503001), Natural Science Foundation of Guangdong Province (Grant No. 2016A030313354), Guangzhou Sci \& Tech Bureau (Grant No. 201607010042) and Fundamental Research Funds for the Central Universities for financial support of this work. The authors would like to thank the above funding.

Conflicts of Interest: The authors declare no conflict of interest.

\section{References}

1. $\mathrm{Fu}, \mathrm{Z} . W . ;$ Meng, Y.Z. research progress in the phosgene-free and direct synthesis of dimethyl carbonate from $\mathrm{CO}_{2}$ and methanol. In Chemistry beyond Chlorine; Springer International Publishing: Cham, Switzerland, 2016; Chapter 13; pp. 363-386.

2. Zhou, Y.J.; Fu, Z.W.; Wang, S.J.; Xiao, M.; Han, D.M.; Meng, Y.Z. Electrochemical synthesis of dimethyl carbonate from $\mathrm{CO}_{2}$ and methanol over carbonaceous material supported DBU in a capacitor-like cell reactor. RSC Adv. 2016, 6, 40010-40016. [CrossRef]

3. Ono, Y. Catalysis in the production and reactions of dimethyl carbonate, an environmentally benign building block. Appl. Catal. A Gen. 1997, 155, 133-166. [CrossRef]

4. Santos, B.A.V.; Silva, V.M.T.M.; Loureiro, J.M.; Rodrigues, A.E. Review for the direct synthesis of dimethyl carbonate. ChemBioEng Rev. 2015, 1, 214-229. [CrossRef]

5. Tundo, P.; Selva, M. The chemistry of dimethyl carbonate. Accounts Chem. Res. 2002, 35, 706-716. [CrossRef]

6. Jessop, P.G.; Ikariya, T.; Noyori, R. Homogeneous catalysis in supercritical fluids. Chem. Rev. 1999, 99, 475-493. [CrossRef] [PubMed]

7. Han, M.S.; Lee, B.G.; Suh, I.; Kim, H.S.; Ahn, B.S.; Hong, S.I. Synthesis of dimethyl carbonate by vapor phase oxidative carbonylation of methanol over Cu-based catalysts. J. Mol. Catal. A Chem. 2001, 170, 225-234. [CrossRef]

8. Watanabe, Y.; Tatsumi, T. Hydrotalcite-type materials as catalysts for the synthesis of dimethyl carbonate from ethylene carbonate and methanol. Microporous Mesoporous Mater. 1998, 22, 399-407. [CrossRef]

9. Puga, J.; Jones, M.E.; Molzahn, D.C.; Hartwell, G.E. Production of Dialkyl Carbonates from Alkanol, Carbon Monoxide and Oxygen Using a Novel Copper Containing Catalyst, or a Known Catalyst with a Chloro-Carbon Promoter; Dow Chemical Company: Midland, MI, USA, 1995.

10. Jia, G.; Gao, Y.F.; Zhang, W.; Wang, H.; Gao, Z.Z.; Li, C.H.; Liu, J.R. Metal-organic frameworks as heterogeneous catalysts for electrocatalytic oxidative carbonylation of methanol to dimethyl carbonate. Electrochem. Commun. 2013, 34, 211-214. [CrossRef]

11. Cai, Q.H.; Lu, B.; Guo, L.J.; Shan, Y.K. Studies on synthesis of dimethyl carbonate from methanol and carbon dioxide. Catal. Commun. 2009, 10, 605-609. [CrossRef]

12. Akune, T.; Morita, Y.; Shirakawa, S.; Katagiri, K.; Inumaru, $\mathrm{K} . \mathrm{ZrO}_{2}$ nanocrystals as catalyst for synthesis of dimethylcarbonate from methanol and carbon dioxide: Catalytic activity and elucidation of active sites. Langmuir 2018, 34, 23-29. [CrossRef] [PubMed] 
13. Aouissi, A.; Al-Othman, Z.A.; Al-Amro, A. Gas-phase synthesis of dimethyl carbonate from methanol and carbon dioxide over $\mathrm{Co}_{1.5} \mathrm{PW}_{12} \mathrm{O}_{40}$ keggin-type heteropolyanion. Int. J. Mol. Sci. 2010, 11, 1343-1351. [CrossRef] [PubMed]

14. Zhang, Z.F.; Liu, Z.T.; Liu, Z.W.; Lu, J. DMC formation over $\mathrm{Ce}_{0.5} \mathrm{Zr}_{0.5} \mathrm{O}_{2}$ prepared by complex-decomposition method. Catal. Lett. 2009, 129, 428-436. [CrossRef]

15. La, K.W.; Jung, J.C.; Kim, H.; Baeck, S.H.; Song, I.K. Effect of acid-base properties of $\mathrm{H}_{3} \mathrm{PW}_{12} \mathrm{O}_{40} / \mathrm{CexTi1}_{-\mathrm{xO}}$ catalysts on the direct synthesis of dimethyl carbonate from methanol and carbon dioxide: A TPD study of $\mathrm{H}_{3} \mathrm{PW}_{12} \mathrm{O}_{40} /$ CexTi1-xO${ }_{2}$ catalysts. J. Mol. Catal. A Chem. 2007, 269, 41-45. [CrossRef]

16. Wu, X.L.; Xiao, M.; Meng, Y.Z.; Lu, Y.X. Direct synthesis of dimethyl carbonate on $\mathrm{H}_{3} \mathrm{PO}_{4}$ modified $\mathrm{V}_{2} \mathrm{O}_{5}$. J. Mol. Catal. A Chem. 2005, 238, 158-162. [CrossRef]

17. Almusaiteer, $\mathrm{K}$. Synthesis of dimethyl carbonate (DMC) from methanol and $\mathrm{CO}_{2}$ over Rh-supported catalysts. Catal. Commun. 2009, 10,1127-1131. [CrossRef]

18. Bansode, A.; Urakawa, A. Continuous DMC synthesis from $\mathrm{CO}_{2}$ and methanol over a $\mathrm{CeO}_{2}$ catalyst in a fixed bed reactor in the presence of a dehydrating agent. ACS Catal. 2014, 4, 3877-3880. [CrossRef]

19. Stoian, D.; Medina, F.; Urakawa, A. Improving the stability of $\mathrm{CeO}_{2}$ catalyst by rare earth metal promotion and molecular insights in the dimethyl carbonate synthesis from $\mathrm{CO}_{2}$ and methanol with 2-cyanopyridine. ACS Catal. 2018, 8, 3181-3193. [CrossRef]

20. Pimprom, S.; Sriboonkham, K.; Dittanet, P.; Föttinger, K.; Rupprechter, G.; Kongkachuichay, P. Synthesis of copper-nickel/SBA-15 from rice husk ash catalyst fordimethyl carbonate production from methanol and carbon dioxide. J. Ind. Eng. Chem. 2015, 31, 156-166. [CrossRef]

21. Kang, K.H.; Lee, C.H.; Kim, D.B.; Jang, B.; Song, I.K. NiO/ $\mathrm{CeO}_{2}-\mathrm{ZnO}$ Nano-catalysts for direct synthesis of dimethyl carbonate from methanol and carbon dioxide. J. Nanosci. Nanotechnol. 2014, 14, 8693-8698. [CrossRef] [PubMed]

22. Tamboli, A.H.; Chaugule, A.A.; Kim, H. Catalytic developments in the direct dimethyl carbonate synthesis from carbon dioxide and methanol. Chem. Eng. J. 2017, 323, 530-544. [CrossRef]

23. Devaiah, D.; Reddy, L.H.; Park, S.E.; Reddy, B.M. Ceria-zirconia mixed oxides: Synthetic methods and applications. Catal. Rev. 2018, 60, 177-277. [CrossRef]

24. Li, H.S.; Zhong, S.H.; Wang, J.W.; Xiao, X.F. Effect of $\mathrm{K}_{2} \mathrm{O}$ on adsorption and reaction of $\mathrm{CO}_{2}$ and $\mathrm{CH}_{3} \mathrm{OH}$ over $\mathrm{Cu}-\mathrm{Ni} / \mathrm{ZrO}_{2}-\mathrm{SiO}_{2}$ catalyst for synthesis of dimethyl carbonate. Chin. J. Catal. 2001, 22, 353-357.

25. Zhong, S.H.; Li, H.S.; Wang, J.W.; Xiao, X.F. Study on Cu-Ni/ $\mathrm{ZrO}_{2}-\mathrm{SiO}_{4}$ catalyst for direct synthesis of dimethyl carbonate from $\mathrm{CO}_{2}$ and $\mathrm{CH}_{3} \mathrm{OH}$. J. Catal. 2000, 21, 117-120.

26. Zhong, S.H.; Li, H.S.; Wang, J.W.; Xiao, X.F. Study on $\mathrm{Cu}-\mathrm{Ni} / \mathrm{MoO}_{3}-\mathrm{SiO}_{2}$ catalyst for the direct synthesis of dimethyl carbonate from carbon dioxide and methanol. Pet. Process. Petrochem. 2000, 6, 51-55.

27. Zhong, S.H.; Li, H.S.; Wang, J.W.; Xiao, X.F. Cu-Ni/ $\mathrm{V}_{2} \mathrm{O}_{5}-\mathrm{SiO}_{2}$ catalyst for the direct synthesis of dimethyl carbonate from carbon dioxide and methanol. Acta Phys. Chim. Sin. 2000, 16, 226-231.

28. Wu, X.L.; Meng, Y.Z.; Xiao, M.; Lu, Y.X. Direct synthesis of dimethyl carbonate (DMC) using Cu-Ni/VSO as catalyst. J. Mol. Catal. A Chem. 2006, 249, 93-97. [CrossRef]

29. Wang, X.J.; Xiao, M.; Wang, S.J.; Lu, Y.X.; Meng, Y.Z. Direct synthesis of dimethyl carbonate from carbon dioxide and methanol using supported copper $(\mathrm{Ni}, \mathrm{V}, \mathrm{O})$ catalyst with photo-assistance. J. Mol. Catal. A Chem. 2007, 278, 92-96. [CrossRef]

30. Bian, J.; Xiao, M.; Wang, S.J.; Wang, X.J.; Lu, Y.X.; Meng, Y.Z. Highly effective synthesis of dimethyl carbonate from methanol and carbon dioxide using a novel copper-nickel/graphite bimetallic nanocomposite catalyst. Chem. Eng. J. 2009, 147, 287-296. [CrossRef]

31. Bian, J.; Xiao, M.; Wang, S.J.; Lu, Y.X.; Meng, Y.Z. Direct synthesis of DMC from $\mathrm{CH}_{3} \mathrm{OH}$ and $\mathrm{CO}_{2}$ over V-doped Cu-Ni/AC catalysts. Catal. Commun. 2009, 10, 1142-1145. [CrossRef]

32. Chen, H.L.; Wang, S.J.; Xiao, M.; Han, D.M.; Lu, Y.X.; Meng, Y.Z. Direct synthesis of dimethyl carbonate from $\mathrm{CO}$ and $\mathrm{CHOH}$ using $0.4 \mathrm{~nm}$ molecular sieve supported $\mathrm{Cu}-\mathrm{Ni}$ bimetal catalyst. Chin. J. Chem. Eng. 2012, 20, 906-913. [CrossRef]

33. Zhou, Y.J.; Wang, S.J.; Xiao, M.; Han, D.M.; Lu, Y.X.; Meng, Y.Z. Formation of dimethyl carbonate on nature clay supported bimetallic Cu-Ni catalysts. J. Clean. Prod. 2014, 103, 925-933. [CrossRef]

34. Zhang, M.; Alferov, K.A.; Xiao, M.; Han, D.M.; Wang, S.J.; Meng, Y.Z. Continuous dimethyl carbonate synthesis from $\mathrm{CO}_{2}$ and methanol using $\mathrm{Cu}-\mathrm{Ni} @ \mathrm{VSiO}$ as catalyst synthesized by a novel sulfuration method. Catalysts 2018, 8, 142. [CrossRef] 
35. Fu, Z.W.; Yu, Y.H.; Li, Z.; Xiao, M.; Han, D.M.; Wang, S.J.; Meng, Y.Z. Surface reduced $\mathrm{CeO}_{2}$ nanowires for direct conversion of $\mathrm{CO}_{2}$ and methanol to dimethyl carbonate: Catalytic performance and role of oxygen vacancy. Catalysts 2018, 8, 164. [CrossRef]

36. Chen, Y.; Xiao, M.; Wang, S.J.; Han, D.M.; Lu, Y.X.; Meng, Y.Z. Porous diatomite-immobilized Cu-Ni bimetallic nanocatalysts for direct synthesis of dimethyl carbonate. J. Nanomater. 2012, 1-8. [CrossRef]

37. Bonzel, H.P.; Bradshaw, A.M.; Ertl, G. Physics and Chemistry of Alkali Metal Adsorption; Elsevier: Amsterdam, The Netherlands, 1989.

38. Kazi, A.M.; Chen, B.; Goodwin, J.G.; Marcelin, G.; Rodriguez, N.; Baker, T.K. Li ${ }^{+}$promotion of Pd/SiO 2 : The effect on hydrogenation, hydrogenolysis, and methanol synthesis. J. Catal. 1995, 157, 1-13. [CrossRef]

39. Evin, H.N.; Jacobs, G.; Ruiz-Martinez, J.; Thomas, G.A.; Davis, B.H. Low temperaturewater-gas shift: Alkali doping to facilitate formate $\mathrm{C}-\mathrm{H}$ bond cleaving over $\mathrm{Pt} /$ ceria catalysts-An optimization problem. Catal. Lett. 2008, 120, 166-178. [CrossRef]

40. Pigos, J.M.; Brooks, C.J.; Jacobs, G.; Davis, B.H. Low temperature water-gas shift: The effect of alkali doping on the $\mathrm{C}-\mathrm{H}$ bond of formate over $\mathrm{Pt} / \mathrm{ZrO}_{2}$ catalysts. Appl. Catal. A Gen. 2007, 328, 14-26. [CrossRef]

41. Graetsch, H.; Gies, H.; Topalovic, I. NMR, XRD and IR study on microcrystalline opals. Phys. Chem. Miner. 1994, 21, 166-175. [CrossRef]

(C) 2018 by the authors. Licensee MDPI, Basel, Switzerland. This article is an open access article distributed under the terms and conditions of the Creative Commons Attribution (CC BY) license (http://creativecommons.org/licenses/by/4.0/). 